Вісник Національного університету “Львівська політехніка": журналістика

№ 2 (2), 2021

UDC 007:304:659.3

https://doi.org/10.23939/sjs2021.02.017

Mariana Kitsa

$\mathrm{PhD}$, associate professor,

Lviv Polytechnic National University,

Department of Journalism and mass communication imkitsa@gmail.com

Maria Kul

M.A., Seneca College, Canada

\title{
CULTURAL AND ENTERTAINMENT PROGRAMS ON TELEVISION: PROBLEMS AND PROSPECTS OF FUNCTIONING
}

\author{
(C) Kitsa Mariana, Kul Maria, 2021
}

Today, cultural issues should be one of the most popular among the viewers of the Ukrainian channels, because such programs affect the level of their education and culture in general. Modern globalization has determined the specifics of socio-cultural dynamics, and media play an important role in this process, demonstrating a channel of translation of the values and content of mass culture, whose stereotypes are widely disseminated in the sociocultural space. Media in modern society have a significant impact on the formation of value orientations.

Cultural and entertainment programs occupy an important niche on television. Most young people prefer this genre. Therefore, to interest the audience in such a program, you should make great efforts to create an entertaining story. As entertainment TV shows become popular, each show must be individual and different from each other.

As for the recommendations we would like to make to improve cultural and entertainment programs, this is first and foremost a question. Television speech is seen as an important factor in the emotional interaction of the three elements - image, sound and word. But the word plays the most important role in modern television, it is the main "tool" of a journalist's skill.

The desire for purity of speech, its intelligibility - one of the basic professional principles of television journalists. As the analysis of the talk show shows, a skilled presenter is the key to the success of a TV show. The presenter is a person who is first of all aware and constantly enriches his knowledge in a professional way. This is a person who has professional skills, namely: mastery of intonation and timbre of the voice, the manner of gesturing in front of the camera and the work with the camera. A presenter is a creative person who works as a journalist, director, cameraman and editor.

The presenter must be smart, not boring, talented and energetic. After all, such people are required by the viewer in a TV show. Hosts should develop thinking, interpret events and conduct broadcasts in a natural manner and intonation.

The presenter, of course, is a representative of a certain social group, and his interaction can be considered as "representative communication", meaning the common interests, values, ideals and guidelines of this social group. He must present himself to the viewer as a partner in communication.

The establishment of interpersonal contacts in the process of television communication is due to the audiovisual nature of television communication. The viewer receives a message from a specific person, the host of a television program, which is why such a message is personalized. 


\section{Nowadays we can talk about the tendencies of increasing their influence on the formation of general public flavors and needs, as a result of which research and systematization of mechanisms of interaction of mass media and culture in the process of the emergence of modern values is an urgent problem.}

Keywords: culture, TV, entertainment, show, audience, presenter.

Introduction. Today's realities indicate that television has a significant influence on the views, perceptions and ideas of Ukrainian society. Modern trends confirm the observation that television heads the lists of those things that form the personality of ordinary Ukrainians. And although there is still a long way to go, which should be overcome until Ukrainian TV products can be characterized by the word "excellent". Relying on the importance of television, we analyzed the available products on the domestic media market and noted that there is a strong demand among all age groups for the product, which will increase the cultural level of the population and, along with this, will be bright, interesting and well-made.

When we were choosing the topic of our research, we aimed to study the traditional Ukrainian and foreign shows, but during the detailed processing of the information, we found out that there is not much of the cultural elements in the show, so it would be more appropriate to call them cultural entertainment shows.

So, we will consider entertaining programs through the prism of the cultural influence of the journalism.

Purpose of the article is to explore the features of popularization of cultural projects in media on the examples of Ukrainian and foreign talk shows. For the research object, we have taken cultural and entertainment programs on TV channels "CBS" (USA), "BBC One" (Great Britain) and "Novyj kanal" (Ukraine) for 2019-2020 years). The subject of the research is the specificity of the popularization of cultural projects in cultural and entertainment programs on the specified television channels.

Methodology of the research. We have used the following research methods:

1. Theoretical, that allowed to systematize theoretical materials on the topic of research.

2.Empirical, which contributed to the generalization of the information received: monitoring of TV channels, which makes it possible to analyze the features of cultural and entertainment TV programs.

3. The method of a specific sociological research as a way of determining the preferences of the auditor's auditor.

4. Statistical methods for processing the research results. Also, graphical forms of displaying the received information (tables, graphs) were used.

Discussion. We decided to explore the following statements: "Entertainment" and its place on the television, classification of entertainment programs, features and features of entertainment programs, an overview of cultural and entertainment programs on Ukrainian television, attitude of viewers to culturalentertaining television programs and also the results of a specific sociological study.

In our research, we found that cultural journalism is one of the most promising areas for the development and self-actualization of journalists. It gives us extraordinary opportunities for career growth, spiritual and personal self-improvement. However, this, as other branches of journalism, has a number of peculiarities and rules that would not succeed in becoming a truly competent journalist in this field [2, p.14]. Modern culture is oriented on innovation, and a cult of creative personality [5].

Based on the analysis of existing classifications of cultural entertainment programs, we proposed our own classification of entertainment shows on television, taking as a feature for the classification of the content and topics of such television broadcasts:

- information and entertainment programs, where both new information and entertainment take place;

- cultural and entertainment programs;

- humorous entertainment programs; 
- regional studies and entertainment;

- social and entertainment;

- culinary and entertainment;

- mystical and entertaining;

- love-entertaining [1].

And cultural and entertainment programs that we analyze are the diffusion of both entertaining and cognitive, cultural, humorous, and social programs. They perform educational, communicative, educational, entertaining, functions [8]. The great rejection of entertainment TV shows is that almost every broadcast includes a "game" involving not only participants but also viewers. It is the social needs of the population that explains the popularity of the programs [4, p.30]. Entertainment in the TV shows is represented by such elements: passion-competitions, entertainment, distraction from reality, etc.

As a result of our research and analysis, we can conclude that the emergence and aggravation of competition in the Ukrainian media environment has forced TVs to focus on studying the problems of brand formation and the role of positioning Ukrainian TV channels on the media. Brands exist to determine the benefits of television products, as well as to form a certain value - the value of the product. Due to medical brands and positioning strategies, Ukrainian speakers have the opportunity to effectively use their ephir, to timely and accurately determine their niche and format.

One of the methods of attracting the audience to the TV channel is precisely cultural and entertainment programs [11, p. 26]. "Entertainment program" originates from the words "entertainment", "game", "spectacle". The basis of any entertainment program is the game. Any game has a positive impact on the audience, because first and foremost, the games raise the mood of the viewer and energize.

Results. We have reviewed the peculiarities of cultural entertainment shows as well as the main aspects of popularizing cultural projects directly on the example of The Ellen Show (CBS, USA), Olya (Novy Kanal, Ukraine) and The Graham Norton Show (BBC One “, United Kingdom). In order to investigate which entertainment programs the viewers of Ukrainian TV channels are watching, we conducted a survey that interviewed students and teachers, as well as ordinary passers-by in Lviv. We left a total of 100 questionnaires. Interviewed - persons of different sex and different age categories.

More than half of the respondents were women (62\%). With regard to age, $58 \%$ are people aged 18 to 25 years old, another $24 \%$ - from 26 to $35,15 \%$ - from 36 to 45 years old, and $3 \%$ from 46 to 60 years old. Consequently, according to the results, entertainment programs on TV channels 1+1 (46\%), New Channel (28\%) and STB (26\%) are most often viewed by viewers.

Unfortunately, none of our respondents mentioned the talk show "Olya", which we analyze in our work. Perhaps this is because it was released on the air of the New Channel for quite a while, and could not conquer permanent viewers. The last question in the questionnaire was about what program viewers would like to see. This question was open and gave the opportunity to respond based only on their own tastes and wishes in this way, the young people indicated that they lacked programs about the possibility to create their own business, earn money, etc. (34\%, mostly male), as well as programs on beauty and fashion ( 21 $\%$, mostly women). One of the issues also concerned foreign cultural and entertainment television programs, which are viewed by our respondents. This was a matter of open-ended type, and none of the respondents indicated foreign TV programs. This is not surprising, since the viewing of such programs is possible only through satellite or on the Internet, and also provides for the ability to speak foreign languages, as they are broadcast without translation, in this case, in English. Having analyzed the entertainment programs indicated by the respondents, we can note that entertainment shows occupy leading positions in the Ukrainian media space, which gives them a wide opportunity to form the cultural level of society through a prism of lightness.

The subject of the research Ukrainian cultural and entertainment product choose the talk show "Olia", the TV-host of which was well-known journalist Olga Freimut, For the first time the program began to be broadcast on the New Channel on August 28, 2018. A total of one season of this program has 
been broadcast. "Olia". The talk show is entertaining; it focuses on coverage of relevant topics that have been violated within a few days before the broadcast. The project was broadcast on Novy Kanal four days a week - from Tuesday to Friday. In parallel with the analysis of the show as an independent product, we also conducted a research of the results of his perception by the Ukrainian audience.

The main idea of this talk show was built on the discussion of topical issues of social and cultural life with stars of different sizes. The show is an adaptation of the famous American TV show "The Ellen DeGeneres Show", which holds 4 Emmi Awards and 11 times the nominee for this award. The "OLIA" show is the first legal adaptation of the American project in the world [3, 20]. Despite the worldwide recognition of the original source, the show "Olia" crashed. In our opinion, the main reasons for closing this show were:

- cunning behavior of the TV-host;

- evil, sometimes inaccurate jokes Olga Freimut;

- a courageous attitude towards the ordinary people, who in their stories showed Olga Freimut;

- at times the unfriendly attitude to the guests invited by the host to the show "Olia";

- ordinary reaction of the public on one or another episode;

- there is no interactivity. The viewers can not ask questions to guests or the host themselves.

Preliminary image of the TV-host. Olga Freimut is perceived as a vagabond, who sometimes does not feel the tact.

The show by "Helen Degeneres" (often abbreviated to Ellen and stylized under "ellen") is a comedy of American television in the form of a talk show organized by Ellen DeGeneres. Departed on September 8,2003 , the project is produced by Television Images and broadcast by channels owned by NBCUniversal, in particular by CBS (USA). Since 2017, the show has won 59 Emmi awards, including four awards in the nomination "Outstanding Talk Shows" and six in the nomination "Outstanding Entertainment" [22].

The show is based on the frank communication of the TV-host with world-renowned artists, politicians and artists, as well as discussing interesting social issues with seasoned entertainment and jokes with them. All of the above items affect the fact that the show has a large number of fans, both among viewers and among subscribers in social networks. Thousands of reviews are not sharply negative. Instead, the majority are positive, and some reviews contain suggestions or wishes of users to the talk show. Such communication contributes to the continuous improvement of the program.

Reviews, in our opinion, "The show of Elena Degeneres" is very popular among the audience and received a huge number of awards due to this:

- jokes of the manager and the mental features of the spectators;

- you can use a large number of episodes and parts that repeat in different days;

- the program is constantly updated with new headings;

- the TV-host invite well-known people with whom they work the audience;

- the jokes of Helen Degeneres are friendly and help people not to be ashamed of who she is and can laugh at herself;

- the host often tells the curiosities about himself, which makes him like everyone else.

"Helen DeGeneres is a very shocking person, she suddenly appeared in front of the president in a dressing gown, danced with Michelle Obama, etc.

The social aspect of the show, which consists in collecting contests for charity. In this case, the participant earned on the show can donate to charity of his own choice.

The show is extremely interactive, and the show's participants behave relentlessly and have the opportunity to interact at any time with the show.

The "The Graham Norton Show" feature is a British reality talk show that began broadcasting in February 2007 on the BBC TWO channel, and since October 2009 this program has come to BBC One evening on Friday, and usually repeats a few days later. This show is characterized by sharp humor, sometimes sarcasm with elements of criticism, which is often impromptu by the TV-host of the show Grahem Norton [21]. Mostly he invites two guests to his show. They appear at the beginning of the show 
after a small monologue of the presenter about a specific current event, which serves as a podium to what will happen next and on what topic conversation will take place. Sometimes the host invites a few guests. The host chooses guests not by chance.

He first talks about some event or novelty in the field of cinema, art, show business, politics, etc., and then invites guests who are directly related to a particular event. They can be presented right away at the beginning of the show, or some of them may come directly before their performance or when discussing a specific topic.

In general, one can distinguish the following features of the show by Graham Norton:

- specific, sometimes incomprehensible to the Ukrainian audience,

- british humor;

- excessive seduction of the TV-host, which is sometimes manifested in obscene jokes, excessive sarcasticity, and so on;

- professional leadership in behavior;

- the ability to imprompate doing a real show of the show;

- Graham Norton's high skill as an interviewer;

- ability to select such guests, complementing each other;

- thin humor of the TV-show;

- lucky matching of topical topics;

- interaction of the TV-show with the audience, the possibility of present guests to ask the guests or offer them a certain task;

- Graham Norton's greetings during a conversation with the most famous and most respected guests;

- search for additional information and its presentation on the air;

- search for additional information and its presentation on the air;

- readiness of the TV-show to any people who are invited by the public or the guests themselves.

- audience surveys of their unusual skills.

Conclusions. So, the "Graham Norton show", based on the interview as a method of collecting information and talk shows as a television genre, is extremely popular and interesting due to the mastery of the leader who has already become a star not only in Britain but also in many other countries the world.

Regarding the show "Olia", which is the Ukrainian version of Helen DeGeneres program, it unfortunately did not succeed for several reasons. Firstly, this is a mixed attitude of viewers to a leading person, and, secondly, is the failure to take into account the mentality of the Ukrainian viewer. As a result, the show "Olia" has ceased to exist, and the program Helen DeGeneres continues to hit records in world rankings.

Cultural and entertainment programs occupy an important niche on television. Most young people prefer this kind of genre. Therefore, in order to interest the audience with such a transfer, you should make great efforts when creating an entertaining plot. Since entertainment shows are gaining in popularity, each show must be individual and different from each other.

After analyzing cultural and entertainment TV programs, we highlighted their common characteristics:

1. Lightness of the content for perception by the viewer.

2. The spirit of competition, empathy, involvement of the viewer (sms-voting, calls to the studio, participation in contests, etc.).

3. Satisfaction of the viewer from viewing, physical and moral-aesthetic relaxation.

4. Appearance of the program.

5. Creativity of the implementation of the content of the program.

6. Innovation, dissimilarity in organization of carrying out.

7. Individual features of the host. 
However, even the top-ranking international show is not a guarantee of the success of its counterpart in other countries. Consequently, creating the equivalent of foreign shows should take into account the mentality of viewers of a particular country. For example, Graham Norton's jokes might not be perceived by the Ukrainian audience, as well as the behaviors of the presenter. Instead, the format of the program itself, in our opinion, would have been successful in Ukraine.

\section{REFERENCES}

1. Matveeva L. V. (2000). Model of communicative act in television communication. Psychological Journal. 2000. № 2.p. 24

2. Mashchenko I. (1998). Television of Ukraine. K., T. 1, 511 p.

3. "New Channel". Official site of the "New Channel" [Electronic resource]. Access mode: novy.tv/ua/

4. Petrenko V. F. (1986). TV and psychology. Television yesterday and today. Moscow: Moscow Publishing House. University, p. 213

5. Pechenyuk T.(2006). Color science. Kharkiv: Grani, 384 p.

6. Pobereznyakova O. (2004). Television interaction: Interactive field of communication. M.: Aspekt Press, $162 \mathrm{p}$.

7. Protsak H. (2016). Means of psychological influence and manipulation of public consciousness. Access mode: http: //www.mediakrytyka.info/za-scho-krytykuyut-media/zasoby-psykho-lohichnoho-vplyvu-ta-manipulyatsiyi.html.

8. Pocheptsov G. G. (1998). Imageology: theory and practice. K.: ADEF-Ukraine, 392 p.

9. Pocheptsov G. G. (2001). Theory of communication. M.: Real-buk, 656 p.

11. Serbenskaya O. A, Babenko V.V (2007). Fundamentals of teleconstruction: Workshop. Lviv: PAIS, 112 p.

12. Slisarenko I. (1998). News is the eyes of the TV channel. Day, 13 March.

13. Sokolov A. G. (1997). The nature of screen creativity. Psychological regularities. M .: Iskusstvo, 256 p.

14. STB. Official site of STB [Electronic resource]. Access mode: www.stb.ua.

15. Fomicheva I. D. (2007). Sociology of mass media : textbook. allowance for university students. M.: Aspekt Press, 355 p.

16. Hunt L. (2001). Fundamentals of television branding and on-air promotion. M.: Galleria, $152 \mathrm{p}$.

17. Sharikov A. (2018). Images of leading news TV programs in expert evaluations: audience study service [Electronic resource]. Access mode: http://evartist.narod.ru/text7/42.htm.

18.. Shepel V. M. (2002). Imageology. How to like people. M.: UNITI, 238 p.

19. Schmidt M. (1999). TV brand as an added value. S.-Pet., 617 p.

20. Olya Show [Electronic resource]. Access mode: https://olia.novy.tv/ua/.

21. The Graham Norton Show [Electronic resource]. Access mode: https://web.archive.org/web/ 20080723132631/http://bbcamerica.com/content/231/index.jsp.

22. The Ellen DeGeneres Show [Electronic resource]. Access mode: http://www.tv.com/shows/the-ellendegeneres-show/.

Мар'яна Кіца, Марія Куль

\section{КУЛЬТУРНО-РОЗВАЖАЛЬНІ ПРОГРАМИ НА ТЕЛЕБАЧЕННІ: ПРОБЛЕМИ ТА ПЕРСПЕКТИВИ ФУНКЩІОНУВАННЯ}

Культурно-розважальні програми займають важливу нішу на телебаченні. Більшість молоді віддає перевагу саме такому жанру. Через це, щоб зацікавити аудиторію такою передачею, потрібно докласти великих зусиль при створенні розважального сюжету. Зважаючи на те, що розважальні телепередачі набувають популярності, кожне шоу має бути індивідуальним і відповідно відрізнятися одне від одного.

Стосовно рекомендацій, котрі ми б хотіли зробити для покращення культурно-розважальних програм, це насамперед мова. Мовлення телебачення розглядають як важливий фактор емоційної взаємодії трьох елементів - зображення, звуку і слова. Проте найважливіше значення в сучасному телебаченні відіграє слово, воно є головним “інструментом" майстерності журналіста. 
Прагнення до чистоти мовлення, його зрозумілості - один $з$ основних професійних принципів тележурналістів. Як показує аналіз ток-шоу, майстерний ведучий с запорукою успіху телепередачі. Ведучий - це людина, яка насамперед є обізнаною і постійно збагачує свої знання в професійному руслі. Це особа, яка має професійні навики, а саме: володіння інтонацісю та тембром голосу, манера жестикуляції перед камерою і сама робота 3 камерою. Ведучий - це творча людина, яка виконус роботу журналіста, режисера, оператора та редактора.

Ведучий мас бути розумним, ненудним, талановитим та енергійним. Адже, саме таких людей вимагає глядач в телепередачі. Ведучі мають розвивати думку, інтерпретувати події та проводити ефіри $з$ природньою манерою та інтонацісю.

Ведучий, безумовно, с представником певної соціальної групи, і його взаємодію можна розглядати як, “представницьке спілкування”, тобто спільні інтереси, цінності, ідеали і настанови цісї групи. Він повинен сам представляти себе глядачеві як партнера у спілкуванні.

Встановлення міжособистісних контактів у процесі телевізійного спілкування відбувається завдяки аудіовізуальному характеру телевізійної комунікації. Глядач одержус повідомлення від конкретної особи, ведучого телевізійної передачі, саме тому таке повідомлення має персоніфікований характер.

Ключові слова: культура, телебачення, розвага, шоу, аудиторія, ведучий. 